\title{
Evaluating yield and related trait of Haricot Bean varieties at Dambi Dollo University Research Site, Ethiopia
}

\author{
Itefa Degefa ${ }^{1 *}$, Abdisa Abriham ${ }^{2} \&$ Soresa Shuma ${ }^{3}$ \\ ${ }^{1}$ Department of Biotechnology, College of Natural and Computational Science, Dambi Dollo University, 260 Dambi Dollo, Ethiopia \\ ${ }^{2}$ Department of Natural Resource Management, College of Agriculture and Veterinary Medicine, Dambi Dollo University, 260 Dambi Dollo, \\ Ethiopia \\ ${ }^{3}$ Department of Animal Science, College of Agriculture and Veterinary Medicine, Dambi Dollo University, 260 Dambi Dollo, Ethiopia \\ *Email: ittafaadaggafaa@gmail.com
}

\section{ARTICLE HISTORY}

Received: 07 May 2021

Accepted: 16 June 2021

Available online: 01 July 2021

KEYWORDS

parameters

performance

released

agronomic

\section{ABSTRACT}

Haricot bean (Phaseolus vulagris L.) is an annual crop cultivated for food as it has high protein content. The objective of this study was to evaluate yield and yield-related traits of haricot bean varieties at the Dollo University research site. Five released and four local haricot bean varieties were used on $3 \times 2 \mathrm{~m}$ $\left(6 \mathrm{~m}^{2}\right)$ experimental plots using randomized complete block design with three replications. Data pertaining to agronomic traits and yield performance of each variety were recorded and analyzed using $\mathrm{R}$ software version 4.0.5 and Microsoft Excel 2010. One way multivariate analysis showed a significant difference $(p<0.05)$ in thousand seed weight. SAB-632, Local-4 ('Burree') and SAB-736 showed higher yield than the other haricot bean varieties. They are also high in all agronomic traits except SAB-736. Thousand seed weight and yield were high and significant with positively correlated to each other. Plant height had a high and significant positive correlation with the number of branches and seeds per plant. Generally, it is possible to say that haricot bean varieties, SAB-632 and Local-4('Burree') are preferable in yield at the Dambi Dollo University research site according to the present findings. Therefore, it is good if these two haricot bean varieties are practised for multiplication at Dambi Dollo Research site and other related agro ecologies.

\section{Introduction}

Haricot bean (Phaseolus vulagris L.) is an important source of protein, calories and cash for smallholder farmers (1). It is a favourable vegetable because of its delicious taste and moderate price, available throughout the year (2). The crop is an annual crop that belongs to the family Fabaceae (1) and cultivated primarily for dry seeds, green pods (as snap beans), and green-shelled seed (3). Haricot bean is locally known as "Boleqe" or common bean, and is an important legume crop and one of the most widely cultivated species of Phaseolus in Ethiopia. The crop is grown on an area of about $166000 \mathrm{htr}$ and ranks third in the area among legumes with an average yield of $800 \mathrm{~kg} / \mathrm{htr}$ (4).

Haricot bean is grown predominantly in low land area $(300-1100 \mathrm{~m})$, mainly in the rift valley and some mid highland areas (1400-2000 m). It requires a warm, frost-free climate, but the plant may drop its flowers or pods during excessively hot or rainy weather (2). It cannot tolerate frost or elevations above $3000 \mathrm{~m}$ but can grow as annuals in temperate climates.
Potential haricot bean varieties released by Ethiopian Agricultural Research centres should be tested in different areas where not tested before to expand its production area and increase productivity (1). This study evaluated the yield and related traits of haricot bean varieties at the Dambi Dollo University research site.

\section{Materials and Methods}

\section{Description of the Study Areas}

The field experiment was conducted at Dambi Dollo University research site, Oromia regional state, Ethiopia, during the July-September under rain fed growing conditions of 2020. A testing site has the potential for haricot bean cultivation. The sites are located at a latitude and longitude of $8^{\circ} 55^{\prime} \mathrm{N}$ and $34^{\circ} 54^{\prime} \mathrm{E}$ with an elevation of $1580 \mathrm{~m}$ above sea level.

\section{Experimental Design and Layout}

Nine haricot bean varieties namely 'SAB-736', 'NASIR', 'BOLE', 'AWASH-2', 'SAB-632', 'Local-1('Gad-Tuulee')', 
'Local-2 ('Naziret')', 'Local-3 ('Diimtuu')' and 'Local-4 ('Burree')' were used to evaluate one which shows good performance in yield and related traits on the open field agro-ecological condition of the site. The experiment was laid out in a randomized complete block design (RCBD) with three replications. Five released varieties ('SAB-736', NASIR', 'BOLE', 'AWASH-2' and 'SAB-632') were collected from Awash Melkasa Agricultural Research Center (AMARC) and four local varieties (Local-1('Gad-Tuulee'), Local-2 ('Naziret'), Local-3 ('Diimtuu')' and Local-4 ('Burree')) were collected from the local market.

The size of the experimental plots was $3 \times 2 \mathrm{~m}$ $\left(6 \mathrm{~m}^{2}\right)$ with $1 \mathrm{~m}$ spacing between blocks and $0.5 \mathrm{~m}$ between plots. Each plot had eight rows. The interrow and intra-row spacings were $40 \mathrm{~cm}$ and $10 \mathrm{~cm}$, respectively. The central five rows were randomly used for data collection. All agronomic practices such as land preparation and weeding were performed.

\section{Data Collection}

Yield and Yield components of haricot bean were collected by selecting five plants from central rows to avoid the border effect. Plant height was recorded by measuring the height of five selected plants from each plot from base to the tip of the main branch using measuring tape when they are physically maturiture, and the average was recorded, the number of branches per plant was recorded by counting the branches of five selected plants from each plot and average was recorded, the number of pods per plant was recorded by counting pods of five selected plants from each plot and average was recorded, the number of seed per pod was recorded by counting seeds of ten pods per plant of five selected plants from each plot and average was taken, 1000 seed weight were taken by counting 1000 seed from each plot and measured using digital weighing balance expressed in gm and yield data were recorded by threshing seeds of all haricot bean from $3 \times 2 \mathrm{~m}$ area and measured using digital weighing balance and changed to $\mathrm{kg} / \mathrm{htr}$.

\section{Statistical Analysis}

Data were analyzed using $\mathrm{R}$ version 4.0.5 and Microsoft Excel 2010. Multivariate analysis (MANOVA) between agronomic traits of haricot bean varieties was evaluated at a 5\% significance level. Correlation and regression analysis were computed to assess the relationships between yield and yield components of the haricot bean varieties at the experimental site.

\section{Results and Discussion}

Statistical values of all yield and yield-related components were computed together, and the yield of tested haricot bean varieties falls between 836.70$2611.00 \mathrm{~kg} / \mathrm{htr}$ as shown in Table 1 . Analysis of variance revealed that there was a significant difference $(p<0.05)$ among varieties in 1000 seed weight from all recorded parameters (Table 2).

\section{Agronomic Traits}

There were no significant differences $(\mathrm{p}<0.05)$ among haricot bean varieties for pods per plant. More pods per plant were recorded from the variety SAB-632 (18.40). On the other hand, the lowest number of pods per plant was recorded from AWASH-2 variety with a pod per plant of 10.13 (Table 3).

It was investigated that there was no significant difference in plant height. But, relatively Local-4 ('Burree'), SAB-632 and Local-1 ('Gad-Tuulee') varieties are high in plant height while SAB-736 is the least.

SAB-632, Local-1 ('Gad-Tuulee') and Local-4 ('Burree') varieties are the highest 6.07, 5.07 and 5.00 respectively while Local-2 ('Naziret') variety is the least one in the number of branches.

Haricot bean varieties revealed variation $(p<$ 0.05 ) for the number of seeds per plant. The variety SAB-632 produced more seeds per pod (5.67) compared to the other varieties. On the other hand, SAB-736 produced the lowest number of seeds per pod (3.41) (Table 3). Local-4('Burree'), Local-1 ('GadTuulee') and NASIR are relatively higher in seed per plants than other haricot bean varieties. The present study indicates these varieties are more competent than other haricot bean varieties by their seed per plant in the study site.

The haricot bean varieties tested had a significant variation $(p<0.05)$ among each other for 1000 seed weight. The variety SAB-632 produced the highest 1000 seed weight (366.67 gm). The variety Local-2 (Naziret) was the least in seed weight (203.33 gm) (Table 3). This significant difference in 1000 seed weight may be the difference in genetic makeup, seed size or moisture-holding capacity of the varieties. According to an earlier report (5), NASIR has a 20.9 gm 1000 seed weight is less than the result of the present study.

It has been evaluated that the yield of haricot bean varieties varies from each other. SAB-632 showed the highest yield $(2106.89 \mathrm{~kg} / \mathrm{htr})$ followed by Local-4 ('Burree') which is $1809.33 \mathrm{~kg} / \mathrm{htr}$. SAB-736, Local-3 ('Diimtuu') and BOLE are relatively high when compared to other varieties respectively. The least variety in yield is AWASH-2 and Local-2 ('Naziret') respectively (Table 3 ). This shows that a variety that performs best in a certain environment may not be as productive in another area (5).

\section{Correlation and Regression Analysis of Haricot Bean Agronomic Traits}

An analysis of correlation and regression between each agronomic trait of haricot bean varieties at the study site was done. Yield is high and positive significantly correlated with thousand seed weight and low with seed per plant. Plant height has high and showed a significant positive correlation with both branches and seeds per plant. This shows that the increment of plant height increases the number of branches and seeds per plant. The rest traits were positively correlated with yield and with each other, 
Table 1. Statistical values of each agronomic traits of Haricot Bean

\begin{tabular}{|c|c|c|c|c|c|c|}
\hline & YLD & TSW & PH & BR & PPP & SPP \\
\hline Minimum & 836.70 & 180 & 23.60 & 2.80 & 6.80 & 2.73 \\
\hline Median & 1760.00 & 270 & 38.80 & 4.60 & 10.80 & 5.00 \\
\hline Mean & 1652.20 & 283 & 40.78 & 4.61 & 12.09 & 4.85 \\
\hline Maximum & 2611.00 & 460 & 61.00 & 6.60 & 23.00 & 6.76 \\
\hline S. Error of Mean (S. Em.) & 167.13 & 32.45 & 5.81 & 0.52 & 1.75 & 0.39 \\
\hline CV\% & 23.34 & 25.85 & 31.67 & 20.94 & 32.45 & 20.41 \\
\hline
\end{tabular}

Where: YLD=Yield in Kg, SW=1000 Seed Weight, PH=Plant Height, BR=Branches, PPP=Pods per Plant, SPP=Seeds per Plant

Table 2. Summary of one way Multivariate Analysis of Variance (MANOVA)

\begin{tabular}{|c|c|c|c|c|c|}
\hline & Df & Sum Sq & Mean Sq & F value & $\operatorname{Pr}(>F)$ \\
\hline TSW & 1 & 1006293 & 1006293 & 9.480 & $0.00569 * *$ \\
\hline $\mathrm{PH}$ & 1 & 223407 & 223407 & 2.105 & 0.16163 \\
\hline$\overline{\mathrm{BR}}$ & 1 & 65348 & 65348 & 0.616 & 0.44144 \\
\hline$\overline{\mathrm{PPP}}$ & 1 & 29402 & 29402 & 0.277 & 0.60420 \\
\hline SPP & 1 & 313217 & 313217 & 2.951 & 0.10055 \\
\hline Residuals & 21 & 2229124 & 106149 & & \\
\hline
\end{tabular}

Where: TSW=1000 Seed Weight, PH=Plant Height, BR=Branches, PPP=Pods per Plant, SPP=Seeds per Plant

Table 3. Mean values of yield and other related traits of each haricot bean varieties

\begin{tabular}{|c|c|c|c|c|c|c|}
\hline Varieties & YLD & TSW & PH & BR & PPP & SPP \\
\hline SAB-736 & 1798.89 & 326.67 & 25.27 & 4.27 & 10.20 & 3.41 \\
\hline NASIR & 1566.00 & 283.33 & 45.73 & 4.47 & 11.40 & 5.51 \\
\hline BOLE & 1735.00 & 296.67 & 30.40 & 4.00 & 10.87 & 4.93 \\
\hline AWASH-2 & 1033.22 & 246.67 & 32.20 & 4.60 & 10.13 & 4.69 \\
\hline SAB-632 & 2106.89 & 366.67 & 53.07 & 6.07 & 18.40 & 5.67 \\
\hline Local-1('Gad-Tuulee’) & 1653.67 & 223.33 & 48.80 & 5.07 & 14.67 & 5.48 \\
\hline Local-2('Naziret') & 1393.78 & 203.33 & 37.30 & 3.87 & 10.60 & 4.98 \\
\hline Local-3('Diimtuu') & 1773.33 & 253.33 & 37.67 & 4.13 & 12.20 & 3.44 \\
\hline Local -4('Burree') & 1809.33 & 346.67 & 56.60 & 5.00 & 10.33 & 5.55 \\
\hline
\end{tabular}

Where: YLD=Yield in Kg, SW=1000 Seed Weight, $\mathrm{PH}=$ Plant Height, BR=Branches, PPP=Pods per Plant, SPP=Seeds per Plant

Table 4. Correlation analysis between yield and related traits of haricot bean varieties

\begin{tabular}{|c|c|c|c|c|c|c|}
\hline & YLD & TSW & PH & BR & PPP & SPP \\
\hline YLD & 1 & & & & & \\
\hline TSW & $0.510^{* *}$ & 1 & & & & \\
\hline $\mathrm{PH}$ & 0.358 & 0.245 & 1 & & & \\
\hline $\mathrm{BR}$ & 0.418 & 0.385 & $0.583^{* *}$ & 1 & & \\
\hline PPP & 0.104 & 0.116 & 0.376 & 0.437 & 1 & \\
\hline SPP & 0.002 & 0.141 & $0.629 * *$ & 0.418 & 0.335 & 1 \\
\hline
\end{tabular}

Where: YLD=Yield in Kg, SW=1000 Seed Weight, $\mathrm{PH}=$ Plant Height, BR=Branches, PPP=Pods per Plant, SPP=Seeds per Plant, Significant codes 0 “***’0.001 ‘**, 0.01 ‘*, 0.05 '? 0.1 ' ' 1

Table 5. Regression analysis of haricot bean parameters on yield

\begin{tabular}{|c|c|c|c|c|}
\hline & Estimate & Std. Error & t value & Pr. $(>|\mathbf{t}|)$ \\
\hline (Intercept) & 960.4690 & 414.5491 & 2.317 & $0.0307^{*}$ \\
\hline TSW & 2.0447 & 0.9498 & 2.153 & $0.0431^{*}$ \\
\hline $\mathrm{PH}$ & 11.5882 & 7.1700 & 1.616 & 0.1210 \\
\hline $\mathrm{BR}$ & 89.5307 & 89.8272 & 0.997 & 0.3303 \\
\hline PPP & -5.9897 & 18.5325 & -0.323 & 0.7497 \\
\hline SPP & -144.2135 & 83.9539 & -1.718 & 0.1006 \\
\hline Significant codes & $0^{\text {(**** }}$ & $0.001^{\text {‘**, }}$ & $0.01^{\text {'* }}$ & 0.05 '?0.1 \\
\hline
\end{tabular}

although there were no significant variation between them.

The intercept estimate value of all traits with yield is high, and a significant difference is there. It has been evaluated that there was a significant positive correlation between yield and thousand seed weight, which has a high value of prediction, as shown in Fig. 1. A-E.

\section{Conclusion}

The study was conducted at Dambi Dollo University Research Site, Ethiopia with the objective to evaluate yield and related traits of haricot bean varieties. The result showed that there was a significant difference in 1000 seed weight. SAB-632, Local-4 ('Burree') and SAB736 showed higher yield than the rest of the varieties. These varieties are also high in agronomic traits except SAB-736. 1000 seed weight and yield were high and positive significantly correlated with each other. Plant height was high and positive significantly correlated with the number of branches and seeds per plant.

It is possible to say that SAB-632 and Local-4 ('Burree') are the best varieties in yield at the Dambi Dollo university research site, Ethiopia and similar agro ecology according to the finding of the present study. Therefore, it is preferable to practice these two varieties for multiplication at this site and related agro-ecology. 

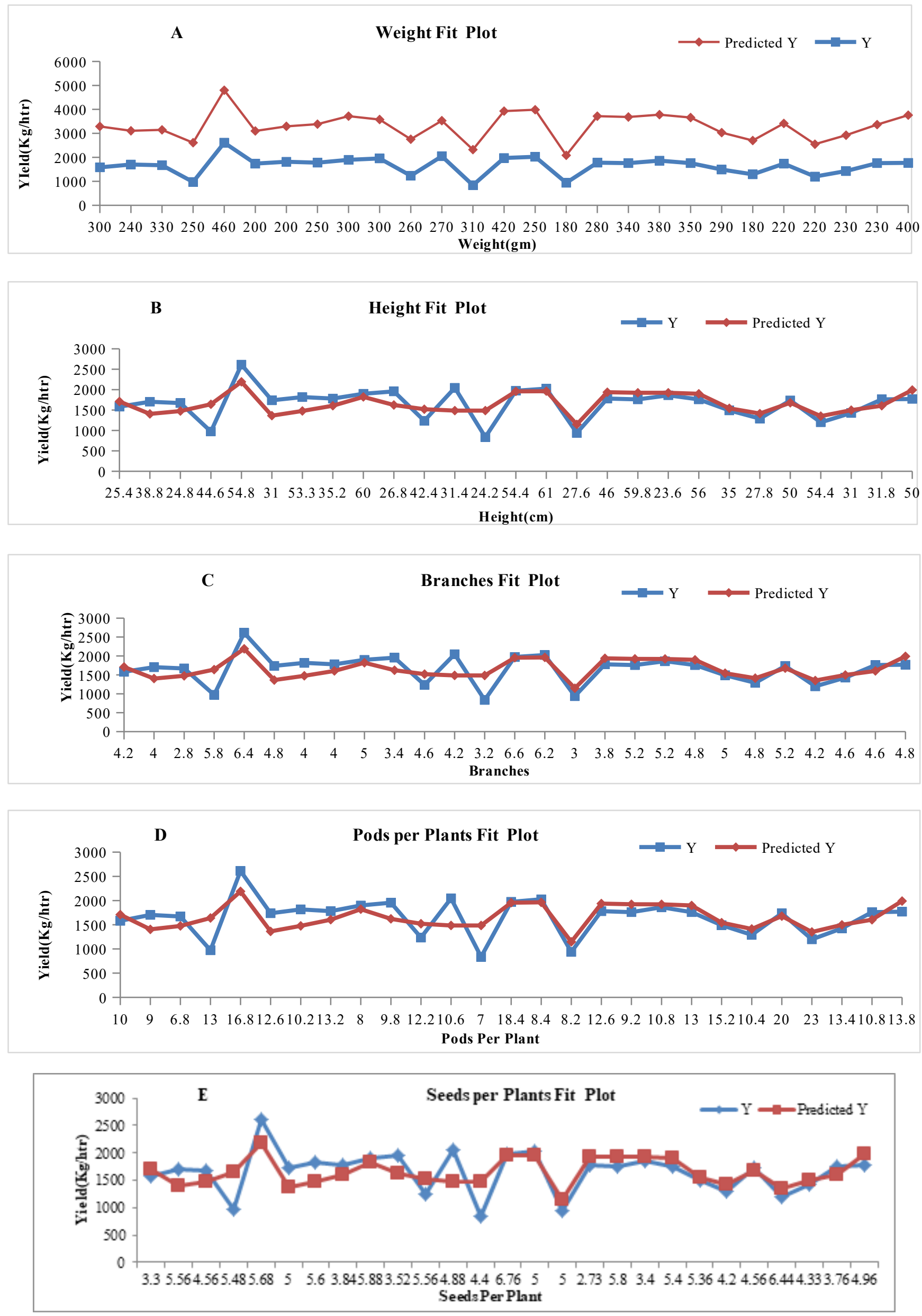

Fig. 1. A-E: Measured and predicted values of yield and yield related traits of haricot bean. 


\section{Acknowledgements}

Dambi Dollo University, Ethiopia and Awash Melkasa Agricultural Research Center (AMARC) are highly acknowledged for their funding and providing haricot bean varieties respectively.

\section{Authors' contributions}

Soresa Shuma and Abdisa Abriham have contributed to the present study by collecting plant materials, plantation, onsite management and data collection. Itefa Degefa contributed to the present study by data collection, data analysis with interpretation and writing for publication.

\section{Conflict of interests}

There is no conflict of interest.

\section{References}

1. Gebre-egziabher M, Hadush T, Abay F. Agronomic performance of some haricot bean varieties (Phaseolus vulgaris L.) with and without phosphorus fertilizer under irrigated and rain fed conditions in the Tigray and Afar regional states, northern Ethiopia. Momona Ethiop J Sci. 2014;6(2):95-09.

2. Alhrout H, Dalaeen H, Haddad M. The impact of organic and inorganic fertilizer on yield and yield components of common bean (Phaseolus vulgaris L.). Adv Environ Biol. 2016;10(9):8-13. Available from: http://www.aensiweb.com/AEB/

3. Keba HA. Adaptability evaluation of common bean (Phaseolus vulgaris L.) genotypes at Western Ethiopia. J Agric Biotechnol Sustain Dev. 2018;10(7):140-46.

4. Abate S, Katiyar M. Yield components and yield of haricot bean (Phaseolus vulgaris L.) under different irrigation frequency and planting density treatments. African J Plant Sci Biotechnol. 2012;6(1):13-20.

5. Worku W. Haricot Bean Production Guide: with emphasis on southern Ethiopia (English version). Publication is Sponsored by Project 'Scaling-up Pulse Innov Food Nutrition Security South Ethiopia' which is Supported by Can Int Food Secur Res Fund Hawassa. June 2015.

Additional information

Peer review information: Plant Science Today thanks Sectional Editor and the other anonymous reviewers for their contribution to the peer review of this work.

Reprints and permissions information is available at

https://horizonepublishing.com/journals/index.php/PST/open_access_policy

Publisher's Note: Horizon e-Publishing Group remains neutral with regard to jurisdictional claims in published maps and institutional affiliations.

To cite this article: Degefa I, Abriham A, Shuma S. Evaluating yield and related trait of Haricot Bean varieties at Dambi Dollo University Research Site, Ethiopia. Plant Science Today. 2021;8(3):669-673.

https://doi.org/10.14719/pst.2021.8.3.1252

Plant Science Today, published by Horizon e-Publishing Group, is covered by Scopus, Web of Science, BIOSIS Previews, Clarivate Analytics, etc. See https://horizonepublishing.com/journals/index.php/PST/indexing_abstracting 